\title{
POLICIES TO ENABLE BIOENERGY DEPLOYMENT KEY CONSIDERATIONS AND GOOD PRACTICES
}

Sharon Smolinski and Sadie Cox

National Renewable Energy Laboratory

Prepared for the U.S. Department of Energy and the

Australian Government Office of Industry, Innovation and Science

NREL/TP-7A40-66322

May 2016 


\section{POLICIES TO ENABLE BIOENERGY DEPLOYMENT KEY CONSIDERATIONS AND GOOD PRACTICES}

Sharon Smolinski and Sadie Cox

National Renewable Energy Laboratory

Prepared for the U.S. Department of Energy and the

Australian Government Office of Industry, Innovation and Science

NREL/TP-7A40-66322

May 2016 


\section{NOTICE}

This manuscript has been authored by employees of the Alliance for Sustainable Energy, LLC ("Alliance") under Contract No. DE-AC36-08GO28308 with the U.S. Department of Energy ("DOE”).

This report was prepared as an account of work sponsored by an agency of the United States government. Neither the United States government nor any agency thereof, nor any of their employees, makes any warranty, express or implied, or assumes any legal liability or responsibility for the accuracy, completeness, or usefulness of any information, apparatus, product, or process disclosed, or represents that its use would not infringe privately owned rights. Reference herein to any specific commercial product, process, or service by trade name, trademark, manufacturer, or otherwise does not necessarily constitute or imply its endorsement, recommendation, or favoring by the United States government or any agency thereof. The views and opinions of authors expressed herein do not necessarily state or reflect those of the United States government or any agency thereof. 


\section{Acknowledgments}

The authors would like to thank Ron Benioff, Victoria Healey, Laura Vimmerstedt, and Terri Walters of the National Renewable Energy Laboratory for their review and insights. 


\section{Table of Contents}

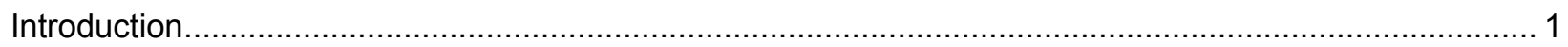

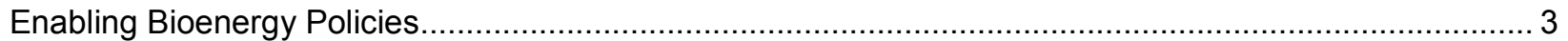

Renewable Electricity Standards ................................................................................ 3

Good Practices and Considerations ............................................................................. 3

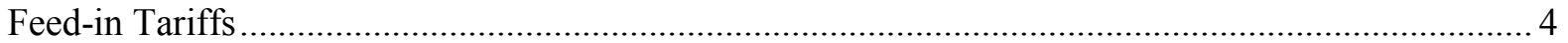

Good Practices and Considerations .............................................................................. 4

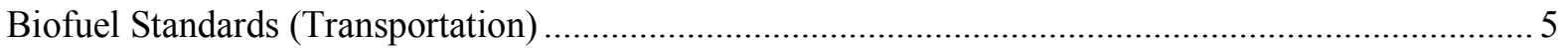

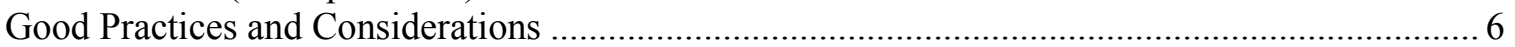

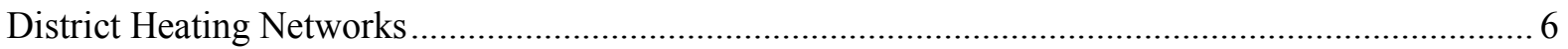

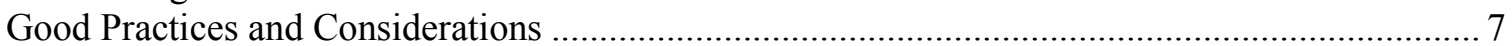

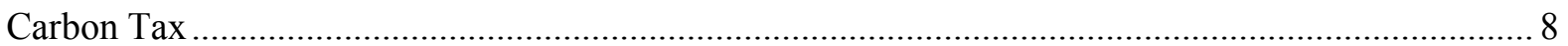

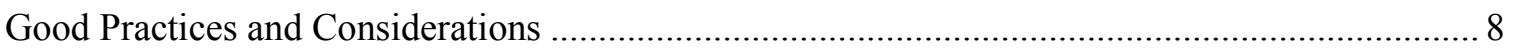

Sustainability Standards and Certification ...................................................................... 9

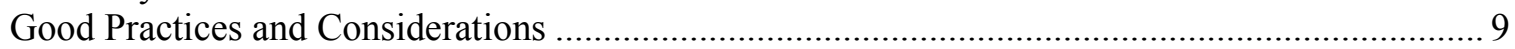

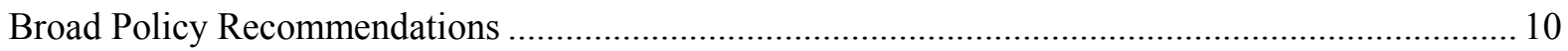

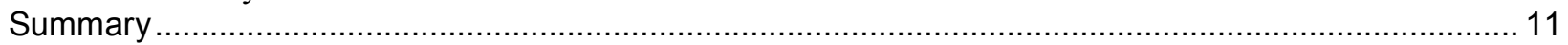

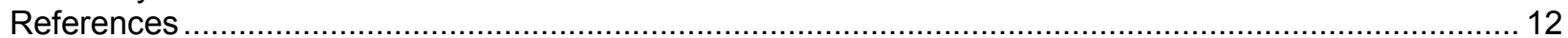

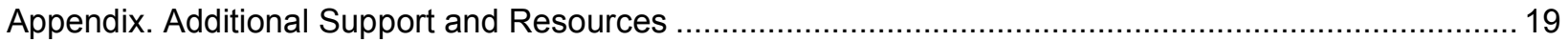




\section{Introduction}

Bioenergy is renewable energy generated from biological source materials, and includes electricity, transportation fuels and heating. Source materials are varied types of biomass, including food crops such as corn and sugarcane, non-edible lignocellulosic materials such as agricultural and forestry waste and dedicated crops, and municipal and livestock wastes. Fuels produced from the conversion of these materials include biodiesel and bioethanol liquid biofuels, and biogases. Some solid fuels can be used following relatively little processing, demonstrated by the direct combustion of densified wood chips. These varied fuels can be utilized alone or in conjunction with conventional fossil fuels, as in blends of bioethanol with gasoline, and the co-firing of wood and coal. Furthermore, fuels can be applied towards multiple end uses, including from within shared facilities which can co-generate electricity and heat. In these ways, bioenergy allows for diverse end uses from a variety of biologically based sources and fuel types.

While renewable electricity generation includes contributions from solar photovoltaic, wind, and hydropower technologies, an increasing amount of generation is supplied by biopower generated from biomass (REN21 2015; Pacini et al. 2014). In 2014, global biopower capacity increased to 93 gigawatts $(\mathrm{GW})$, with 433 terawatt-hours (TWh) generated (REN21 2015). ${ }^{1}$ In the transportation sector, most renewable fuels are liquid biofuels, although the use of biogases is increasing (REN21 2015). Global annual biofuel production increased in 2014 to 94 billion liters of bioethanol and 29.7 billion liters of biodiesel, both led by the United States and Brazil (REN21 2015). ${ }^{2}$ There is increased trade in liquid biofuels, involving developed and developing countries, and including activity beyond regions of production (UNCTAD 2014). While the primary market for liquid biofuels continues to be road vehicles, newer markets include aviation and other transportation sectors (REN21 2015; Souza et al. 2015a; Pacini et al. 2014). In addition, bioenergy accounts for most of the heating provided by renewable energy sources, which collectively supplied $8 \%$ of the global consumption of heat in 2014 (REN21 2015). Bioenergy, across all of its subcategories, supported an estimated 3 million jobs in 2014 (Ferroukhi et al. 2015).

Policies that support bioenergy deployment generally align with goals that include mitigation of climate change, increased economic development, improved access to energy, and increased energy security (Acosta et al. 2015; REN21 2015; Pacini et al. 2014).

While bioenergy capacity and generation have increased, several barriers to deployment exist, including:

- Use of edible food crops for biofuels raises significant concerns over impacts to food security (Acosta et al. 2015; REN21 2015).

- Demand for biomass, both edible crops and (non-edible) lignocellulosic feedstocks, can impact land utilization and ecosystem stability (Acosta et al. 2015; REN21 2015).

- Determination of greenhouse gas (GHG) emissions from bioenergy would benefit from improved and consistent methodologies for life cycle analysis and land use changes (Macedo et al. 2015).

\footnotetext{
${ }^{1}$ The top countries for electricity generation from biopower include the United States, Germany, China, Brazil, and Japan. The top countries for increased capacity are China, Brazil, and Japan (REN21 2015).

${ }^{2}$ The top countries for biodiesel production are the United States, Brazil, Germany, Indonesia, and Argentina. The top countries for bioethanol production are the United States, Brazil, China, Canada, and Thailand (REN21 2015).
} 
- Subsidies for traditional fuels and nuclear power limit cost competitiveness (REN21 2015). ${ }^{3}$

- Uncertainty and sudden significant changes in policy hinder deployment (REN21 2015).

- Infrastructure and regulation is designed for single fuel deployment (REN21 2015).

- Policy development for the heating and cooling sector, including mandates for bioenergy in buildings, is insufficient (REN21 2015).

Key aspects of policies for bioenergy deployment are presented here as part of the Clean Energy Solutions Center's Clean Energy Policy Brief Series. The policies presented specifically or broadly cover electricity generation, transportation, and heating. Policymakers can adapt these practices in the design of country-specific bioenergy policies.

\footnotetext{
${ }^{3}$ Subsidies for fossil fuels and nuclear power are estimated at USD 550 billion to USD 5.6 trillion/year (REN21 2015).
} 


\section{Enabling Bioenergy Policies}

A variety of mandates and market mechanisms facilitate the deployment of bioenergy in the form of electricity generation, transportation fuels, and heating. Electricity generation is one primary focus of renewable energy policies (REN21 2015), and the policy mechanisms employed for biopower are shared with other renewable power sources such as solar and wind, and include standards and feed-in tariffs (FITs). Bioenergy transportation policies include biofuels standards requiring the utilization of specified amounts of liquid and/or gas biofuels. While policies for heating from renewables are seen as underdeveloped (REN21 2015), district heating networks allow for the use of varied biomass sources for increased energy efficient heating in urban areas. Some policy mechanisms are more goal-based, such as carbon tax policies and sustainability standards and certification, which are more generally focused on decreased carbon emissions. Additional policy recommendations include integrating related policies (such as agricultural and water), integrating diverse energy sources and technologies in comprehensive policies, and assisting developing countries. While many of the policy mechanisms presented here focus on end-use, sustainability standards and certification directly govern biomass sourcing and production. Other policy mechanisms are closely aligned with complementary policies that directly support the production of advanced fuels from biomass feedstocks, as demonstrated by the alignment between biofuel standards and mandates requiring the production of biofuels. Selected good practices and considerations are given for each policy mechanism.

\section{Renewable Electricity Standards}

Mandates such as renewable electricity standards (RESs) set requirements for a certain amount of energy to be generated from renewable energy sources (Cox and Esterly 2016a). RESs are one of the common renewable electricity policies (REN21 2015). As of 2015, renewable electricity mandates have been established in 26 countries at the national level and in 72 states or provinces at the subnational level (REN21 2015). These mandates have facilitated the deployment of biopower, including biogas and directly combustible biomass, for electricity generation (Lofthouse, Simmons, and Yonk 2015; REN21 2015; Souza et al. 2015a). Cox and Esterly (2016a) provide a broad summary of RESs, including good practices, at cleanenergysolutions.org/policy-briefs/res.

\section{Good Practices and Considerations}

- Designing mechanisms to measure and track biopower-By designing mechanisms for measuring compliance, policymakers can ensure the identification of suppliers who are out of compliance and improve the overall effectiveness of biopower mandates (Cox and Esterly 2016a). Renewable electricity credits (RECs) represent an amount of biopower generated and can be traded separately from the electricity (Cox and Esterly 2016a; Cory and Swezey 2007; Leon 2012). Credits reduce compliance costs, allowing entities to achieve compliance using various sources and technologies regardless of local site limitations (Cory and Swezey 2007). This pairing of mandates and credits has been applied in the United States, United Kingdom, European Union, Chile, and the Philippines (Azuela and Barros 2011; Devenyi and Mladenov 2012) and offers opportunity for international trade (Devenyi and Mladenov 2012).

- Enforcing non-compliance penalties-Non-compliance penalties, such as fines or alternative compliance payments, can be applied to suppliers who fail to meet standards, thereby encouraging compliance (Cox and Esterly 2016a; Cory and Swezey 2007). To improve the effectiveness of this approach, policymakers can ensure that the penalties are enforced by specifying an amount and means of collection and discouraging suppliers from passing the cost to downstream users (Cory and Swezey 2007). 
- Limiting costs of compliance-By controlling costs of compliance, policymakers can limit excessive detrimental economic impacts to a supplier (Cox and Esterly 2016a; Leon 2012). Tools such as waivers can protect a supplier from penalties if compliance is difficult to achieve (Cox and Esterly 2016a; Leon 2012), while the use of well-defined parameters can ensure these tools are applied appropriately (Cory and Swezey 2007).

- Designing long-term contracts-Policymakers can require long-term contracts between utilities and renewable energy developers (ten to twenty years or more) in order to promote sufficient financing for renewable electricity generation projects (Cory and Swezey 2007; Grace, Donovan and Melnick 2011; Leon 2012). Long-term contracts ensure commitments and an increased likelihood of generating revenue, reducing risks from uncertainties that may be inherent in applying newer technologies (Cory and Swezey 2007; Grace, Donovan and Melnick 2011; Leon 2012).

- Designing provisions for combined heat and power $(\mathrm{CHP})$ - By incorporating requirements for CHP within standards, policymakers can specify the use of biomass for the co-generation of heat and power from a single power plant, increasing energy efficiency (Evans and Douraeva 2004). This approach takes advantage of the diverse fuel types from biomass, as well as the ability to combine biomass-based fuels with fossil fuels (Evans and Douraeva 2004; IEAETSAP 2015). RES provisions can allow CHP to be an eligible biopower source similar to other eligible sources, treated as energy efficiency, or as a

Text Box 1. CHP-Inclusive RES Policy in Arizona

The U.S. state of Arizona established an RES with a target of $15 \%$ of energy provided by renewables by 2025 (DSIRE 2016). Arizona later revised its policy to include a separate but related standard termed Energy Efficiency Resource Standards (EERS), which considers energy efficiency in meeting standards (EPA-CHP 2016). Only CHP that utilizes biomass is eligible for credits under the RES, but non-biomass-fueled CHP may be eligible for the EERS, depending on the technology (EPA-CHP 2016). This is in contrast to some states such as Massachusetts, which does not specify biomassfueled CHP (MA-DOER 2011). specific target (EPA-CHP 2016). Text Box 1 details the inclusion of CHP in Arizona's RES.

\section{Feed-in Tariffs}

FITs facilitate deployment of electricity from renewable energy, including from bioenergy, by resolving market uncertainty through long-term price-controlled agreements (Cox and Esterly 2016b; Couture et al. 2010; Klein et al. 2010). As of 2015, there were 108 FITs in place at the national or subnational level (REN21 2015). In bioenergy, FITs have been used to increase power supplied by biogases and direct biomass combustion (Souza et al. 2015b). Recent trends show an increased diversity in the design and application of FITs, including whether payments apply to partial or full energy produced (Couture et al. 2015). Cox and Esterly (2016b) provide a broad summary of FITs, including good practices, at cleanenergysolutions.org/policy-briefs/fit.

\section{Good Practices and Considerations}

- Differentiating FIT payments based on technology and fuel type-Policymakers can differentiate FIT payments based on technology and fuel type. This can support specific technologies that are most compatible with the local context while setting separate payments for each type based on the expected energy and revenue generation (Couture et al. 2010). This approach allows policymakers to pursue varied types of energy sources, priced according to the expected 
performance for each, regardless of higher costs to implement some technologies (Couture et al. 2010; Klein et al. 2010). In addition, projects that use technologies for the co-generation of heat and power from biomass can receive bonus payments to reflect increased efficiency (Couture et al. 2010). Text Box 2a describes a FIT policy in Kenya that includes price differentiation by energy source.

- Differentiating FIT payments based on project size-Policymakers can differentiate FIT payments based on project size in order to roughly equalize the profit from projects with different generation capacities (Couture et al. 2010; Klein et al. 2010). This approach typically assigns higher payments to smaller projects (Couture et al. 2010; Klein et al. 2010). This payment strategy can support projects of varied sizes, creating opportunities for different types of investors (Couture et al. 2010). Text Box 2b describes a FIT policy in Kenya that includes price differentiation by project size.

- Designing long-term contracts and guaranteeing grid access-The use of long-term contracts between utilities and renewable electricity generators can indicate an increased likelihood of generating revenue from a project, thereby increasing the ability to secure sufficient financial support (Cox and Esterly 2016b; Couture et al. 2010). Similarly, establishing guarantees for grid access to renewable projects fosters support by ensuring that electricity generated will be able to enter the market (Cox and Esterly 2016b). Text Box 2c describes a FIT policy in Kenya that includes guarantees for long-term contracts and grid access.

\section{Text Box 2. FIT Policy Design in Kenya}

Kenya instituted a FIT policy in 2008 and revised the policy in 2010 and 2012 to accommodate more diverse energy sources and specific pricing for smaller project sizes (IEA 2014a; IEA 2014b).

Text Box 2a.

FIT policy designed and implemented in Kenya includes multiple types of renewable energy sources, which are assigned different payments. For example, a wind project with $0.5-100 \mathrm{MW}$ of power plant capacity is assigned a tariff of USD 0.12/kWh, while a biomass-based energy source of similar capacity is assigned a lower tariff of USD 0.060.08/kWh (IEA 2014a).
Text Box 2b.

Payments are also differentiated based on project size, reflected in 2012 policy revisions (IEA 2014b). Energy sourced from biomass at a capacity of $0.5-$ $100 \mathrm{MW}$ is assigned a tariff of USD 0.06-0.08/kWh (IEA 2014a), while smaller projects with a maximum capacity of 10 MW capacity are assigned a higher tariff of USD $0.1 / \mathrm{kWh}$ (IEA 2014b).
Text Box 2c.

Kenyan FIT policy sets payments for 20 year periods and requires grid access guarantees from grid system operators, as well as priority purchase, transmission, and distribution (IEA 2014a). The Ministry of Energy has final authority to assess project feasibility (IEA 2014a).

\section{Biofuel Standards (Transportation)}

Mandates such as renewable fuel standards establish requirements for the incorporation of renewable transportation fuels, thereby supporting increased utilization of biofuels (Mosey and Kreycik 2008). As of 2015, 64 mandates require blending biofuels with conventional fuels in 33 countries; 31 at the national level and 26 at the subnational level (REN21 2015). Requirements for the types and blends of biofuels vary considerably across countries and states (Mosey and Kreycik 2008; Lane 2016). 


\section{Good Practices and Considerations}

- Developing and implementing complementary policies Policymakers can support the production and use of biofuels using complementary policies including incentives for the production of biofuels, infrastructure grants for improved equipment necessary for biofuel dispensing, and tax credits for gas stations selling higher biofuel blends (Mosey and Kreycik 2008). Tax incentives for the production of biomass are recommended in order to ensure sufficient feedstocks for production of more advanced fuels - such as biodiesel and bioethanol—and ultimately achievement of mandates for use (Paulsworth 2013). These policies directly and comprehensively encourage and facilitate the deployment of the entire biofuels industry from feedstock cultivation to end use, making it more likely that targets set by mandates will be achieved. Policies supportive of flexible fuel vehicles, which can utilize varied types and blends of biofuels, can contribute to the demand for biofuels, as demonstrated in Brazil (Chum et al. 2015). Text Box 3 discusses complementary biofuel policies in Thailand.

- Designing flexible mandates - Policymakers can design mandates with flexibility to respond to technological and market changes by requiring periodic assessment and adjustment to control renewable fuel costs and increase the overall effectiveness of these policies (Mosey and Kreycik 2008; REN21 2015; RFA 2015). Flexible standards also support technological development of advanced biofuels by providing a potential market for their deployment (Mosey and Kreycik 2008; Souza et al. 2015a).

- Increasing mandates for lignocellulosic biofuels - The increased use of mandates specific to lignocellulosic biofuels can facilitate their development and deployment (Eisentraut 2010; Mosey and Kreycik 2008; Pacini et al. 2014), mitigating some of the challenges related to the competition over crops between biofuels and food (Pacini et al. 2014). These types of biofuels are limited to non-edible materials such as agricultural and forestry waste.

\section{District Heating Networks}

District heating networks allow for the large-scale delivery of heating, commonly in densely populated areas, by generating steam or heated water at a centralized location and delivering to homes and businesses (Bruton et al. 2012; Foust et al. 2015; Leal et al. 2015). Varied biomass sources can be used, including municipal waste, wood, and biogas, allowing for the increased use of 
renewables (Bruton et al. 2009; Ericsson 2009; Foust et al. 2015; Evans and Douraeva 2004; Leal et al. 2015). These large-scale systems allow for the safe use of raw municipal waste that cannot be used in more traditional single-residential heating (Ericsson 2009). Also, district heating systems can be coupled with CHP plants, which allow for the co-generation of heat and power, increasing efficiency while using biomass (Bruton et al. 2012; Ericsson 2009; Evans and Douraeva 2004). These networks can also be utilized for cooling, using the same principles as for heating (Foust et al. 2015). Heating and cooling mandates are not widely implemented and do not always incorporate the potential for heat from bioenergy (REN21 2015).

\section{Good Practices and Considerations}

- Considering diverse applications and fuel sources-Biomass lends itself to diverse applications, particularly when utilized in systems that allow for the co-generation of heat and electricity and the use of varied biomass mixtures and in combination with traditional fossil fuels (Evans and Douraeva 2004; IEA-ETSAP 2015). By designing policies that can harness this flexibility, policymakers can achieve more energy efficient systems, ensuring service at lower costs (Evans and Douraeva 2004). At the same time, policymakers can improve the effectiveness of heating networks by considering the appropriateness of systems and fuels to the local context (Foust et al. 2015). Text Box 4a discusses the use of and support for systems that allow for the co-generation of heat and power in Denmark.

- Financing new infrastructure over the long term - In areas requiring new or updated delivery infrastructure (such as underground piping), the installation costs for district heating systems can be prohibitive (Bruton et al. 2012). By financing new infrastructure through long-term repayment mechanisms, such as through public utilities, policymakers can reduce the cost barrier (Bruton et al. 2012).

- Designing for mandatory participation of consumers - By requiring mandatory use of district heating by consumers, policymakers can ensure a market for the product, reducing product costs and risks to suppliers (Bruton et al. 2012; C40 2011). Text Box 4b shows the use of mandatory participation in district heating networks in Denmark.

- Applying taxation strategies and financial incentives supportive of biomass usagePolicymakers can improve the competitive position of biomass relative to traditional heating fuels by applying a carbon tax and related taxes to traditional fuels while exempting (partially or fully) renewable energy sources (Ericsson 2009). By supporting the use of biomass, policymakers can assist the deployment of biomass-utilization in district heating systems (Ericsson 2009). Text Box 4c shows how Denmark applies taxes and other financial incentives to support of biomass use in district heating networks.

- Considering local context in network design- Policymakers can consider local factors when determining service area and infrastructure placement in order to supply cost-effective district heating (Bruton et al. 2012). These can vary significantly, depending on relative locations and levels of energy usage and fund availability (Bruton et al. 2012). Text Box 4d details the consideration of local context in network design in Denmark. 


\section{Text Box 4. District Heating in Denmark}

Denmark applies several good practices toward the use of district heating networks. Overall, Denmark obtains over half of its heat from district heating networks (Evans and Douraeva 2004), and has also demonstrated decreased carbon emissions and increased gross domestic product (GDP) (State of Green 2016).

\begin{tabular}{|c|c|c|c|}
\hline $\begin{array}{l}\text { Text Box 4a. } \\
\text { CHP plants, which } \\
\text { allow for the co- } \\
\text { generation of heat and } \\
\text { power with district } \\
\text { heating networks, are } \\
\text { used extensively } \\
\text { throughout Denmark } \\
\text { (State of Green 2016). } \\
\text { The use of CHP plants } \\
\text { is supported by } \\
\text { national law requiring } \\
\text { co-generation at larger } \\
\text { plants (Evans and } \\
\text { Douraeva 2004), as } \\
\text { well as subsidies for } \\
\text { CHP plants in } \\
\text { decentralized areas } \\
\text { (DEA/DBDH, n.d.). }\end{array}$ & $\begin{array}{l}\text { Text Box 4b. } \\
\text { In designated and } \\
\text { more centralized } \\
\text { service areas, } \\
\text { consumer participation } \\
\text { in the heating network } \\
\text { is mandatory, } \\
\text { benefiting suppliers by } \\
\text { establishing some } \\
\text { certainty in the market } \\
\text { for the consumption of } \\
\text { heating from district } \\
\text { heating networks } \\
\text { (Bruton et al. 2012). } \\
\text { National law allows } \\
\text { municipalities to } \\
\text { designate the areas } \\
\text { with mandatory } \\
\text { participation, which } \\
\text { can allow for more } \\
\text { cost-effective } \\
\text { networks (Evans and } \\
\text { Douraeva 2004). }\end{array}$ & $\begin{array}{l}\text { Text Box } 4 \mathrm{c} . \\
\text { Biomass used for } \\
\text { district heating is } \\
\text { exempt from a heat } \\
\text { tax that is applied to } \\
\text { traditional fuels } \\
\text { (DEA/DBDH, n.d.). } \\
\text { Also, subsidies are } \\
\text { available for the } \\
\text { development of } \\
\text { decentralized } \\
\text { networks that use } \\
\text { CHP plants } \\
\text { (DEA/DBDH, n.d). }\end{array}$ & $\begin{array}{l}\text { Text Box } 4 d \text {. } \\
\text { Denmark has various } \\
\text { network sizes, serving } \\
\text { both centralized and } \\
\text { less centralized areas, } \\
\text { with varying facilities } \\
\text { and biomass } \\
\text { utilization capacity } \\
\text { (Bruton et al. 2012; } \\
\text { DEA/DBDH, n.d.). }\end{array}$ \\
\hline
\end{tabular}

\section{Carbon Tax}

A carbon tax applies a cost to carbon dioxide $\left(\mathrm{CO}_{2}\right)$ emissions at the point of production or consumption, in effect correcting for negative social and environmental impacts and creating a financial incentive for reducing emissions (C2ES 2013; World Bank 2014). As of 2016, 14 carbon taxes were adopted, 13 at the national level and 1 at the subnational level (British Columbia) (World Bank, n.d.). This includes a tax adopted and put into effect by South Africa in 2016 and a tax adopted by Chile in 2014 and scheduled to be implemented in 2018 (World Bank, n.d.). By creating incentives for energy sources with reduced carbon emissions, this approach has been credited with facilitating the successful deployment of bioenergy (Andersson 2015; Johansson 2000).

\section{Good Practices and Considerations}

- Designing a flexible carbon tax rate to achieve an emissions target-Numerous factors, such as the costs of new emission abatement technologies, influence whether companies choose to reduce emissions instead of paying a carbon tax. These factors make it difficult to predict if emission reduction targets will be achieved (Bowen 2011; C2ES 2013; World Bank 2014). Policymakers can respond to changing conditions by periodically adjusting the emissions target and carbon tax; some recommend reassessment approximately every five years (Bowen 2011). Frequent adjustments can make it difficult to determine the results of such changes because these changes can be affected by numerous factors external to the carbon tax policy (Bowen 2011). While many 
policies anticipate an increase in the carbon tax rate over time (Bowen 2011; C2ES 2013), this may not always be the case (Bowen 2011). Text Box 5 outlines successful carbon tax policy in Sweden, which has utilized flexible, increasing tax rates (Andersson 2015).

- Focusing on upstream producers to reduce implementation costs - A carbon tax can be designed to target upstream producers, midstream suppliers, or downstream consumers (Bowen 2011; C2ES 2013). To avoid the substantial administrative costs of implementing a tax on an extensive population of downstream consumers, many recommendations focus on targeting the smaller number of upstream producers (Bowen 2011; C2ES 2013).
Text Box 5. Flexible Carbon Tax Policy in Sweden

A carbon tax is considered a significant force behind the increased use of bioenergy in Sweden, which includes CHP from biomass (Andersson 2015; Ericsson 2009; Johansson 2000). Sweden's carbon tax has increased from USD 44 per metric ton of carbon dioxide when first applied in 1991, (Sumner, Bird and Smith 2009) to USD 168 per metric ton of carbon dioxide in 2014, the highest globally (World Bank, n.d.). Sweden has simultaneously experienced strong growth in GDP and decreased emissions (Nordic Council of Ministers, n.d.). While the carbon tax complements an existing energy tax (Sumner, Bird, and Smith 2009), analysis indicates that carbon tax increased bioenergy use (Johansson 2000).

\section{Sustainability Standards and Certification}

Sustainability standards and certification designate criteria for biomass utilized for bioenergy, whether in the form of solid biomass for heating and electricity or liquid biofuels used for transportation fuels and electricity. These standards establish requirements for acceptable sourcing and production in order to ensure actual reductions in carbon emissions as well as environmental goals such as the preservation of biodiversity (EC 2016; Souza et al. 2015a). These standards can limit or prevent detrimental practices such as illegal logging of critical forests to obtain internationally traded wood biomass, practices that can decrease the benefits of bioenergy (Souza et al. 2015a).

\section{Good Practices and Considerations}

- Aligning national and international standards -Efforts to improve alignment between national sustainability standards and international trade-based sustainability standards can improve participation and strengthen markets (Souza et al. 2015a; UNCTAD 2014). Discontinuities between some national- and international-level trade standards can have negative impacts on participation in international markets (UNCTAD 2014).

- Developing and applying technical capacity - In order to establish and apply sustainability standards, technical capacity must be developed, both in terms of setting well-defined criteria as well as the means for
Text Box 6. Sustainability Criteria and Measurement Strategies Developed by the European Commission

The European Commission established detailed sustainability criteria for biofuels, including initial requirements for a reduction of $35 \%$ in greenhouse gas emissions compared to traditional fuels, a percentage which increases over time (EC 2016). They provide a protocol that establishes how to calculate greenhouse gas emissions and includes complete life cycle analyses (Alberici and Hamelinck 2010; EC 2016). Additional protocols specify allowable data sources, methods for on-site assessment, and definitions of concepts such as biodiversity and biodiverse areas (Dehue et al. 2011). 
measuring specified parameters (Endres et al. 2015; Souza et al. 2015a; Zarrilli 2008). Text Box 6 details some of the efforts by the European Commission to develop parameters and measurements. This technical capacity must be passed along through the supply and production chain, including working with producers in developing countries where there may be decreased technical resources and varied conditions (Endres et al. 2015; Souza et al. 2015a; Zarrilli 2008).

\section{Broad Policy Recommendations}

- Integrating bioenergy policies with water, land, and agricultural policies - The success of bioenergy policies is impacted by site-specific conditions and policies for water, land, and agriculture (Souza et al. 2015a). Policymakers may generate more effective bioenergy policies when a policy is integrated with related policies, such as agricultural production and land-use, thereby helping to achieve multiple goals and alleviate some competition between food and energy for biomass and land (Souza et al. 2015a; UNCTAD 2014). This integrative approach may be supportive of more efficient and informed biomass production.

- Integrating multiple energy sources and technologies in comprehensive policies-Bioenergy is a diverse arena that provides electricity, transportation, and heating from multiple sources of biological material and fuel types. Bioenergy also allows for flexibility by lending itself to the co-generation of end products within shared production facilities, such as both heat and electricity from biomass, as well as in combination with traditional fossil fuels, such as co-firing biomass with coal (Evans and Douraeva 2004; IEA-ETSAP 2015; REN21 2015). Policymakers may improve the effectiveness of energy policies by integrating multiple energy sources and technologies (IEA-ETSAP 2015; REN21 2015), while considering their appropriateness (Foust et al. 2015).

- Assisting developing countries-Developing countries can face a number of challenges in developing and applying new technologies and policies, including infrastructure development (Pacini and Badtidzirai 2011; Pacini et al. 2014) and dissemination of knowledge (Souza et al. 2015a). Because developing countries may bear higher costs in implementing standards and may have different socio-economic challenges than developed countries (Souza et al. 2015a; Zarrilli 2008; UNCTAD 2014), policies can be improved by incorporating input from developing countries, such as in the development of sustainability standards and their implementation (Endres et al. 2015; Souza et al. 2015a; Zarrilli 2008). Furthermore, developing countries may benefit from policy analysis assistance (Pacini et al. 2014) and from support for producers to participate in global markets (Zarrilli 2008; Pacini et al. 2014). 


\section{Summary}

Table 1 summarizes the good practices and considerations for the design and implementation of bioenergy policies that are presented in this paper.

Table 1. Summary of Good Practices and Considerations

\begin{tabular}{|c|c|}
\hline Policy & Good Practices and Considerations \\
\hline $\begin{array}{l}\text { Renewable Electricity } \\
\text { Standards }\end{array}$ & $\begin{array}{l}\text { Designing mechanisms to measure and track biopower } \\
\text { Enforcing non-compliance penalties } \\
\text { Limiting costs of compliance } \\
\text { Designing long-term contracts } \\
\text { Designing provisions for CHP }\end{array}$ \\
\hline Feed-in Tariffs & $\begin{array}{l}\text { Differentiating FIT payments based on technology and fuel type } \\
\text { Differentiating FIT payments based on project size } \\
\text { Designing long-term contracts and guaranteeing grid access }\end{array}$ \\
\hline $\begin{array}{l}\text { Biofuel Standards } \\
\text { (Transportation) }\end{array}$ & $\begin{array}{l}\text { Developing and implementing complementary policies } \\
\text { Designing flexible mandates } \\
\text { Increasing mandates for lignocellulosic biofuels }\end{array}$ \\
\hline District Heating Networks & $\begin{array}{l}\text { Considering diverse applications and fuel sources } \\
\text { Financing new infrastructure over the long term } \\
\text { Designing for the mandatory participation of consumers } \\
\text { Applying taxation strategies and financial incentives supportive of } \\
\text { biomass usage } \\
\text { Considering local context in network design }\end{array}$ \\
\hline Carbon Tax & $\begin{array}{l}\text { Designing a flexible carbon tax rate to achieve emissions target } \\
\text { Focusing on upstream producers to reduce implementation costs }\end{array}$ \\
\hline $\begin{array}{l}\text { Sustainability Standards and } \\
\text { Certification }\end{array}$ & $\begin{array}{l}\text { Aligning national and international standards } \\
\text { Developing and applying technical capacity }\end{array}$ \\
\hline Broad Recommendations & $\begin{array}{l}\text { Integrating bioenergy policies with water, land, and agricultural policies } \\
\text { Integrating multiple energy sources and technologies in } \\
\text { comprehensive policies } \\
\text { Assisting developing countries }\end{array}$ \\
\hline
\end{tabular}




\section{References}

Acosta, Lillith A., Damasa B. Magcale-Macandog, K. S. Kavi Kumar, Xuefeng Cui, Elena A. Eugenio, Paula, Beatrice M. Macandog, Arnold R. Salvacion, and Jemimah Mae A. Eugenio. 2015. The Role of Bioenergy in Energy-Food Ecosystem Nexus in Asia. APN Global Change Perspectives Policy Brief No. LCD-03. Kobe: Asia-Pacific Network for Global Change Research. http://www.apn-gcr.org/2015/11/09/policy-brief-the-role-of-bioenergy-in-energyfood-ecosystem-nexus-in-asia-lcd-03-2/.

Alberici, Sacha, and Carlo Hamelinck. 2010. Annotated Example of a GHG Calculation Using the EU Renewable Energy Directive Methodology. Project number PEGENLO83540. London: Ecofys. https://ec.europa.eu/energy/sites/ener/files/2010 bsc example ghg_calculation.pdf.

Andersson, K. 2015. Bioenergy: The Swedish Experience. Stockholm: Svebio. https://www.svebio.se/sites/default/files/Bioenergy\%20in\%20Sweden_web.pdf.

Azuela, Gabriela Elizondo, and Luiz Augusto Barroso. 2011. Design and Performance of Policy Instruments to Promote the Development of Renewable Energy: Emerging Experience in Selected Developing Countries. Paper number 22. Washington, D.C.: World Bank Group. http://siteresources.worldbank.org/EXTENERGY2/Resources/DiscPaper22.pdf.

Bowen, Alex. 2011. The case for carbon pricing: Policy brief. London: Grantham Research Institute in Climate Change and the Environment. http://www.lse.ac.uk/GranthamInstitute/wpcontent/uploads/2014/02/PB case-carbon-pricing Bowen.pdf

Bruton, Tom, Steve Luker, Fred Tottenham, and Paddy Donovan. 2012. District Heating as an Enabling Technology for Biomass in the Western Region. Ballaghaderreen, Ireland: Regional Approaches to Stimulating Local Renewable Energy Solutions. http://www.raslres.eu/wpcontent/uploads/2011/06/RASLRES-District-Heating-Public-Sector-WR.pdf.

C2ES (Center for Climate and Energy Solutions). 2013. Options and Considerations for a Federal Carbon Tax. Arlington, VA: C2ES. http://www.c2es.org/docUploads/optionsconsiderations-federal-carbon-tax.pdf.

C40 Cities. 2011. "Case study: 98\% of Copenhagen city heating supplied by waste heat." Copenhagen: C40 Cities. http://www.c40.org/case studies/98-of-copenhagen-city-heatingsupplied-by-waste-heat.

Chum, Helena L., Francisco E. B. Nigro, Robert McCormick, Gregg T. Beckham, Joaquim E. A. Seabra, Jack Saddler, Ling Tao, Ethan Warner, and Ralph P. Overend. 2015. "Conversion Technologies for Biofuels and their Use." In Bioenergy and Sustainability: Bridging the Gaps, edited by Glaucio M. Souza, Reynaldo L. Victoria, Carolos A. Joly, and Luciano M. Verdade, 374-467. Paris: Scientific Committee on Problems of the Environment. http://bioenfapesp.org/scopebioenergy/index.php/chapters.

Cory, K.S., and B.G. Swezey. 2007. Renewable Portfolio Standards in the States: Balancing the Goals and Implementation Strategies. NREL/TP-670-41409. Golden, CO: National Renewable Energy Laboratory. http://www.nrel.gov/docs/fy08osti/41409.pdf. 
Couture, Toby D., David Jacobs, Wilson Rickerson, and Victoria Healey. 2015. The Next Generation of Renewable Electricity Policy: How Rapid Change is Breaking Down Conventional Policy Categories. NREL/TP-7A40-63149. Golden, CO: National Renewable Energy Laboratory. http://www.nrel.gov/docs/fy15osti/63149.pdf.

Couture, Toby D., Karlynn Cory, Claire Kreycik, and Emily Williams. 2010. A Policymaker's Guide to Feed-In Tariff Policy Design. NREL/TP-6A2-44849.Golden, CO: National Renewable Energy Laboratory. http://www.nrel.gov/docs/fy10osti/44849.pdf.

Cox, Sadie, and Sean Esterly. 2016a. Renewable Electricity Standards: Good Practices and Design Considerations. TP-7A40-65507. Golden, CO: Clean Energy Solutions Center. http://www.nrel.gov/docs/fy16osti/65507.pdf.

Cox, Sadie, and Sean Esterly. 2016b. Feed-in Tariffs: Good Practices and Design Considerations. TP-7A40-65503. Golden, CO: Clean Energy Solutions Center. http://www.nrel.gov/docs/fy16osti/65503.pdf.

DEA/DBDH (Danish Energy Agency and Danish Board of District Heating). n.d. District heating: Danish and Chinese experience. Copenhagen: Danish Energy Agency. http://www.ens.dk/sites/ens.dk/files/energistyrelsen/Nyheder/district heating danishchinese experiences.pdf

Dehue, Bart, Liliana Gamba, Gemma Toop, Radhika Murti, Nadine McCormick, Niels Wielaard, and Stephan Mantel. 2011. Inventory of data sources and methodologies to help Economic Operators identify land status: Relating to EU sustainability criteria for biofuels and bioliquids. Project number: PEGENLO83540. Utrecht, Netherlands: Ecofys. https:/ec.europa.eu/energy/sites/ener/files/2011 bsc inventory of data_sources and methodo logies.pdf.

Devenyi, Roland, and Irina Mladenov. 2012. International Markets for Renewable Energy Certificates (RECS). Cambridge, MA: Sustainability Roundtable, Inc. http://sustainround.com/library/sites/default/files/SRER_Member\%20Briefing_International $\% 20$ Markets\%20for\%20Renewable\%20Energy\%20Certificates_2012-07-16.pdf.

DSIRE. 2016. Renewable Energy Standard. Last modified March 18. http://programs.dsireusa.org/system/program/detail/268.

EC (European Commission). 2016. "Sustainability criteria.” Last modified April 20. https://ec.europa.eu/energy/en/topics/renewable-energy/biofuels/sustainability-criteria.

Eisentraut, Anselm. 2010. Sustainable production of second-generation biofuels: potential and perspectives in major economies and developing countries. Paris: International Energy Agency. https://www.iea.org/publications/freepublications/publication/second generation biofuels.pdf. 
Endres, Jody, Rocio Diaz-Chavez, Stephen R. Kaffka, Luc Pelkmans, Joaquim E.A. Seabra, and Arnaldo Walter. 2015. "Sustainability certification." In Bioenergy and Sustainability: Bridging the Gaps, edited by Glaucio M. Souza, Reynaldo L. Victoria, Carolos A. Joly, and Luciano M. Verdade, 660-680. Paris: Scientific Committee on Problems of the Environment. http://bioenfapesp.org/scopebioenergy/index.php/chapters.

EPA-CHP (U.S. Environmental Protection Agency Combined Heat and Power Partnership). 2016. Portfolio Standards and the Promotion of Combined Heat and Power. Washington, D.C.: U.S. Environmental Protection Agency. https://www.epa.gov/sites/production/files/201507/documents/portfolio_standards_and the promotion_of_combined heat and power.pdf.

Ericsson, Karin. 2009. Introduction and development of the Swedish district heating systems: Critical factors and lessons learned. Freiburg, Germany: RES-H Policy Project. http://www.resh-policy.eu/downloads/Swedish district heating case-study \%28D5\%29 final.pdf.

Evans, M., and E. Douraeva. 2004. IEA (International Energy Agency) and OECD (Organization for Economic Co-operation and Development. 2004. Coming in from the Cold: Improving District Heating Policy in Transition Economies. Paris: International Energy Agency. https://www.iea.org/publications/freepublications/publication/cold.pdf.

Ferroukhi, Rabia, Arslan Khalid, Alvaro Lopez-Peña, and Michael Renner. 2015. Renewable Energy and Jobs: Annual Review 2015. Abu Dhabi: International Renewable Energy Agency. http://www.irena.org/DocumentDownloads/Publications/IRENA_RE_Jobs_Annual_Review_201 5.pdf.

Foust, Thomas D., Doug Arent, Isaias de Carvalho Macedo, Jose Goldemberg, Chanakya Hoysala, Rubens Maciel Filho, Francisco E. B. Nigro, Tom L. Richard, Jack Saddler, Jon Samseth, and Chris R. Somerville. 2015. "Energy security." In Bioenergy and Sustainability: Bridging the Gaps, edited by Glaucio M. Souza, Reynaldo L. Victoria, Carolos A. Joly, and Luciano M. Verdade, 60-89. Paris: Scientific Committee on Problems of the Environment. http://bioenfapesp.org/scopebioenergy/index.php/chapters.

Grace, Robert C., Deborah A. Donovan, and Leah L. Melnick. 2011. When renewable energy policy objectives conflict: A guide for policymakers. Silver Spring, MD: National Regulatory Research Institute. http://regulationbodyofknowledge.org/wpcontent/uploads/2013/09/Grace When_Renewable_Energy.pdf.

IEA (International Energy Agency). 2014a. "Kenya: Revised feed-in-tariffs for renewable energy." Last modified October 10. http://www.iea.org/policiesandmeasures/pams/kenya/name24779-en.php.

IEA (International Energy Agency). 2014b. "Kenya: 2nd revision of Feed-in tariffs for Renewable Energy." Last modified October 10. http://www.iea.org/policiesandmeasures/pams/kenya/name-127280-en.php. 
IEA-ETSAP (International Energy Agency, Energy Technology Systems Analysis Program) and IRENA (International Renewable Energy Agency). 2015. Biomass for Heat and Power:

Technology Brief. Paris: International Energy Agency. http://www.irena.org/DocumentDownloads/Publications/IRENA-

ETSAP_Tech_Brief_E05_Biomass\%20for\%20Heat\%20and\%20Power.pdf.

Johansson, Bengt. 2000. Economic Instruments in Practice 1: Carbon Tax in Sweden. Paris: The Organization for Economic Cooperation and Development.

http://www.oecd.org/science/inno/2108273.pdf.

Klein, Arne, Erik Merkel, Benjamin Pfluger, Anne Held, Mario Ragwitz, Gustav Resch, and Sebastian Busch. 2010. Evaluation of different feed-in-tariff design options. 3rd edition. Berlin: German Ministry for the Environment, Nature Conservation and Nuclear Safety.

http://www.feed-in-cooperation.org/wDefault 7/download-

files/research/Best practice Paper_3rd edition.pdf.

Lane, Jim. 2016. "Biofuels mandates around the world: 2016." Biofuels Digest, January 3. http://www.biofuelsdigest.com/bdigest/2016/01/03/biofuels-mandates-around-the-world-2016/.

Leal, Manoel Regis L.V., Louise Jean Claude Autrey, Bundit Fungtammasan, Douglas L. Karlen, Isaias de Carvalho Macedo, Graham von Maltitz, David J. Muth Jr., Jon Samseth, Zilmar Jose de Souza, Luuk van der Wielen, and Heather Youngs. 2015. "Case Studies." In Bioenergy and Sustainability: Bridging the Gaps, edited by Glaucio M. Souza, Reynaldo L. Victoria, Carolos A. Joly, and Luciano M. Verdade, 490-527. Paris: Scientific Committee on Problems of the Environment. http://bioenfapesp.org/scopebioenergy/index.php/chapters.

Leon, Warren. 2012. Designing the Right RPS: A Guide to Selecting Goals and Program Options for a Renewable Portfolio Standard. Montpelier, VT: Clean Energy States Alliance.http://www.cesa.org/assets/2012-Files/RPS/CESA-RPS-Goals-and-Program-DesignReport-March-2012.pdf.

Lofthouse, Jordan, Randy T. Simmons, and Ryan M. Yonk. 2015. Reliability of Renewable Energy: Biomass. Logan: Utah State University. http://www.usu.edu/ipe/wpcontent/uploads/2015/11/Reliability-Biomass-Full-Report.pdf.

Macedo, Isaias de Carvalho, Andre M. Nassar, Annette L. Cowie, Joaquim E. Seabra, Luisa Marelli, Martina Otto, Michael Q. Wang, and Wallace E. Tyner. 2015. "Greenhouse Gas Emissions from Bioenergy." In Bioenergy and Sustainability: Bridging the Gaps, edited by Glaucio M. Souza, Reynaldo L. Victoria, Carolos A. Joly, and Luciano M. Verdade, 582-616. Paris: Scientific Committee on Problems of the Environment.

http://bioenfapesp.org/scopebioenergy/index.php/chapters.

MA-DOER (Massachusetts Department of Energy Resources). 2011. Alternative Energy Portfolio Standards (APS): APS Guideline on the Eligibility and Metering of Combined Heat \& Power Projects. Boston, MA: Department of Energy Resources, Commonwealth of Massachusetts. http://www.mass.gov/eea/docs/doer/rps-aps/aps-chp-guidelines-jun14-2011.pdf. 
Mosey, Gail, and Claire Kreycik. 2008. State Clean Energy Practices: Renewable Fuel Standards. NREL/TP-670-43513.Golden, CO: National Renewable Energy Laboratory. http://www.nrel.gov/docs/fy08osti/43513.pdf.

Nordic Council of Ministers. n.d. Sweden: GDP, Energy, Consumption and Greenhouse Gas Emissions. Copenhagen: Nordic Council of Ministers. http://www.norden.org/en/nordic-councilof-ministers/ministers-for-co-operation-mr-sam/sustainable-development/indicators-forsustainable-development-1/sustainable-use-of-the-earths-resources/decoupling-ofenvironmental-pressures-gross-energy-consumption-ressource-use-and-generation-of-nonmineral-waste-from-economic-growth/sweden-2013-gdp-energy-consumption-and-greenhousegas-emissions.

Pacini, Henrique, Alessandro Sanches-Pereira, Maria Durleva, Malick Kane, and Arpit Bhutani. 2014. The State of the Biofuels Market: Regulatory, Trade and Development Perspectives. New York: United Nations. http://unctad.org/en/pages/PublicationWebflyer.aspx?publicationid=1059.

Pacini, Henrique, and Bothwell Batidzirai. 2001. "The Development of Biofuels Capacities: Strengthening the Position of African Countries through Increased Energy Security." In Bioenergy for Sustainable Development and International Competitiveness, edited by Francis X. Johnson and Vikram Seebaluck. London: Routledge.

Paulsworth, Ashley. 2013. "Increasing Sustainable Biomass through Production Tax Credits." The Journal of Science Policy and Governance 1(3):1-8. http://www.sciencepolicyjournal.org/uploads/5/4/3/4/5434385/increasing_sustainable biomass t hrough production tax credits.pdf

Preechajarn, Sakchai, and Ponnarong Prasertsri. 2010. Thailand Biofuels Annual 2010. GAIN Report Number TH0098. Washington, D.C.: United States Department of Agriculture Foreign Agricultural Service. http://www.unece.lsu.edu/biofuels/documents/2010Aug/bf10 14.pdf.

REN21 (Renewable Energy Policy Network for the $21^{\text {st }}$ Century). 2015. Renewables 2015: Global Status Report. Paris: REN21. http://www.ren21.net/wp-content/uploads/2015/07/REN12GSR2015_Onlinebook_low1.pdf.

RFA (Renewable Fuels Association). 2015. Renewable Fuel Standard (RFS) Flexibility Provisions. Washington, D.C.: Renewable Fuels Association. http://www.ethanolrfa.org/wpcontent/uploads/2015/11/RFS-Flexibility-Provisions-Talking-Points 1.pdf.

Sorda, Giovanni, Martin Banse, and Claudia Kemfert. 2010. "An overview of biofuel policies across the world." Energy Policy 38(11):6977-6988. 
Souza, Glaucia Mendes, Reynaldo L. Victoria, Luciano M. Verdade, Carlos A. Joly, Paulo Eduardo Artaxo Netto, Heitor Cantarella, Helena L. Chum, Luis Augusto Barbosa Cortez, Rocio Diaz-Chavez, Erick Fernandes, Geoffrey B. Fincher, José Goldemberg, Luiz Augusto Horta Nogueira, Brian J. Huntley, Francis X. Johnson, Stephen Kaffka, Angela Karp, Manoel Regis L. V. Leal, Stephen P. Long, Lee R. Lynd, Isaias de Carvalho Macedo, Rubens Maciel Filho, André M. Nassar, Francisco E. B. Nigro, Patricia Osseweijer, Tom L. Richard, Jack N. Saddler, Jon Samseth, Vikram Seebaluck, Chris R. Somerville, Luuk van der Wielen, Marie-Anne Van Sluys, Jeremy Woods, and Heather Youngs. 2015a. "Technical Summary.” In Bioenergy and Sustainability: Bridging the Gaps, edited by Glaucio M. Souza, Reynaldo L. Victoria, Carolos A. Joly, and Luciano M. Verdade, 8-26. Paris: Scientific Committee on Problems of the Environment. http://bioenfapesp.org/scopebioenergy/index.php/chapters.

Souza, Glaucia Mendes, Reynaldo L. Victoria, Luciano M. Verdade, Carlos A. Joly, Paulo Eduardo Artaxo Netto, Heitor Cantarella, Helena L. Chum, Rocio Diaz-Chavez, Erick Fernandes, Geoff Fincher, José Goldemberg, Luiz Augusto Horta Nogueira, Brian J. Huntley, Francis X. Johnson, Angela Karp, Manoel Regis L.V. Leal, Lee R. Lynd, Isaias de Carvalho Macedo, Rubens Maciel Filho, Mariana P. Massafera, André M. Nassar, Francisco E.B. Nigro, Patricia Osseweijer, Tom L. Richard, Jack N. Saddler, Jon Samseth, Vikram Seebaluck, Chris R. Somerville, Luuk van der Wielen, Marie-Anne Van Sluys, Jeremy Woods, and Heather Youngs. 2015b. "Bioenergy Numbers." In Bioenergy and Sustainability: Bridging the Gaps, edited by Glaucio M. Souza, Reynaldo L. Victoria, Carolos A. Joly, and Luciano M. Verdade, 28-57. Paris: Scientific Committee on Problems of the Environment. http://bioenfapesp.org/scopebioenergy/index.php/chapters.

State of Green. 2016. District Energy: Energy Efficiency for Urban Areas. Copenhagen: State of Green. http://dbdh.dk/wp-content/uploads/8855.pdf.

Sumner, Jenny, Lori Bird, and Hillary Smith. 2009. Carbon Taxes: A Review of Experience and Policy Design Considerations. NREL/TP-6A2-47312. Golden, CO: National Renewable Energy Laboratory. http://www.nrel.gov/docs/fy10osti/47312.pdf.

UNCTAD (United Nations Conference on Trade and Development). 2014. The Global Biofuels Market: Energy Security, Trade and Development. UNCTAD Policy Brief No. 30, October. New York: United Nations. http://unctad.org/en/PublicationsLibrary/presspb2014d3 en.pdf.

World Bank. 2014. State and Trends of Carbon Pricing 2014. Washington, D.C.: World Bank. http://www-

wds.worldbank.org/external/default/WDSContentServer/WDSP/IB/2014/05/27/000456286 2014 0527095323/Rendered/PDF/882840AR0Carbo040Box385232B00OUO090.pdf.

World Bank. n.d. Putting a Price on Carbon with a Tax. Washington, D.C.: World Bank. http://www.worldbank.org/content/dam/Worldbank/document/SDN/background-note_carbontax.pdf. 
Youngs, Heather, Luiz Augusto Horta Nogueira, Chris R. Somerville, and Jose Goldemberg. 2015. "Perspectives on Bioenergy." In Bioenergy and Sustainability: Bridging the Gaps, edited by Glaucio M. Souza, Reynaldo L. Victoria, Carolos A. Joly, and Luciano M. Verdade, 230-56. Paris: Scientific Committee on Problems of the Environment. http://bioenfapesp.org/scopebioenergy/index.php/chapters.

Zarrilli, Simonetta. 2008. Making Certification Work for Sustainable Development: The Case of Biofuels. New York: United Nations. http://unctad.org/en/docs/ditcted20081_en.pdf. 


\section{Appendix. Additional Support and Resources}

The following resources can be used to support more detailed design and implementation of policies to support bioenergy deployment. Targeted technical assistance regarding the design and implementation of renewable energy policies is provided by:

- Clean Energy Solutions Center-The Solutions Center's Ask an Expert service is available at no cost to government agency representatives from any country and the technical institutes assisting them. If your request qualifies for assistance, you will be matched with the Solutions Center expert who is most qualified to help you, for up to 40 hours of assistance. To submit a request for assistance, see cleanenergysolutions.org/expert.

- Climate Technology Centre and Network (CTCN) - The CTCN provides technical assistance in response to requests submitted by developing countries via their National Designated Entities. Upon receipt of such requests, the centre quickly mobilizes its global network of climate technology experts to design and deliver a customized solution tailored to local needs. The CTCN does not provide funding directly to countries but instead supports the provision of technical assistance provided by experts on specific climate technology sectors. For more information, see ctc-n.org/technical-assistance.

- Additional resources - including good practice resources and publications, policy examples and databases, webinars and training resources, and a glossary — are available at cleanenergysolutions.org/policy-briefs. 